\title{
Inhibition of Collagenase by Mycosporine-like Amino Acids from Marine Sources
}

\author{
Authors \\ Affiliations \\ Anja Hartmann ${ }^{1}$, Johanna Gostner ${ }^{2}$, Julian E. Fuchs ${ }^{3}$, Eliza Chaita ${ }^{4}$, Nektarios Aligiannis ${ }^{4}$, Leandros Skaltsounis ${ }^{4}$, \\ Markus Ganzera \\ ${ }^{1}$ Institute of Pharmacy, Pharmacognosy, University of Innsbruck, Innsbruck, Austria \\ ${ }^{2}$ Medical Biochemistry, Biocenter, Medical University of Innsbruck, Innsbruck, Austria \\ ${ }^{3}$ Center for Molecular Informatics, Department of Chemistry, University of Cambridge, Cambridge, United Kingdom \\ ${ }^{4}$ Department of Pharmacognosy and Natural Products Chemistry, Faculty of Pharmacy, University of Athens, Athens, Greece
}

\section{Abstract \\ $\nabla$}

Matrix metalloproteinases play an important role in extracellular matrix remodeling. Excessive activity of these enzymes can be induced by UV light and leads to skin damage, a process known as photoaging. In this study, we investigated the collagenase inhibition potential of mycosporinelike amino acids, compounds that have been isolated from marine organisms and are known photoprotectants against UV-A and UV-B. For this purpose, the commonly used collagenase assay was optimized and for the first time validated in terms of relationships between enzyme-substrate concentrations, temperature, incubation time,

\section{Introduction}

$\nabla$

Collagen is the major structural protein in human skin. Consisting of a triple helix scaffold, the tensile strength of its fibers provide structural support for bones, skin, tendons, ligaments, and blood vessels, and are responsible for a dynamic strength of the skin. Mature dermal collagen is formed from precursor molecules called procollagens [1]. Collagenases, which belong to the family of matrix metalloproteinases (MMPs), are transmembrane zinc endopeptidase enzymes. By digesting collagen and elastin fibers, they play important roles in many processes including tissue remodeling during development, tissue homeostasis, and repair after wounding [2]. However, an over activation due to photoaging and chronical aging leads to alterations in the collagen and elastin composition of the extracellular matrix (ECM) and results in wrinkles, laxity, sagging, and a coarse appearance of the human skin $[3,4]$. The upregulation of certain MMPs has been shown to promote cancer progression and to induce angiogenesis by two modes. First, by activating growth factors such as the transforming and enzyme stability. Three compounds were isolated from the marine red algae Porphyra sp. and Palmaria palmata, and evaluated for their inhibitory properties against Chlostridium histolyticum collagenase. A dose-dependent, but very moderate, inhibition was observed for all substances and $\mathrm{IC}_{50}$ values of $104.0 \mu \mathrm{M}$ for shinorine, $105.9 \mu \mathrm{M}$ for porphyra, and $158.9 \mu \mathrm{M}$ for palythine were determined. Additionally, computeraided docking models suggested that the mycosporine-like amino acids binding to the active site of the enzyme is a competitive inhibition.

Supporting information available online at http://www.thieme-connect.de/products

growth factor beta (TGF- $\beta$ ) and the vascular endothelial growth factor (VEGF) and second, by degrading the ECM and E-cadherin molecules, which are important to maintain intercellular interactions [5]. Activity of these enzymes can also be pathologically upregulated in response to UV light exposure (photodamage) or the release of reactive oxygen species (ROS). In addition, in vivo studies prove that UV irradiation results in a reduction of procollagen synthesis [3-5]. Several authors have reported that upregulated MMPs and diminished procollagen synthesis are mechanisms involved in natural skin aging [6,7]. On the contrary, Chung et al. [8] considered a reduced collagen production and a rise in MMP levels typical for naturally aged skin, while in photoaged skin both parameters tend to be enhanced. The observed effect results in collagen depletion due to the much higher amount of MMP.

The discovery of new substances that can prevent connective tissue damage is of great interest for the pharmaceutical and cosmetic industries, and many studies about matrix-metalloproteinase inhibitors from higher plants can be found in the literature [9-11]. Marine organisms are interesting 


\section{Michaelis Menten Equation}

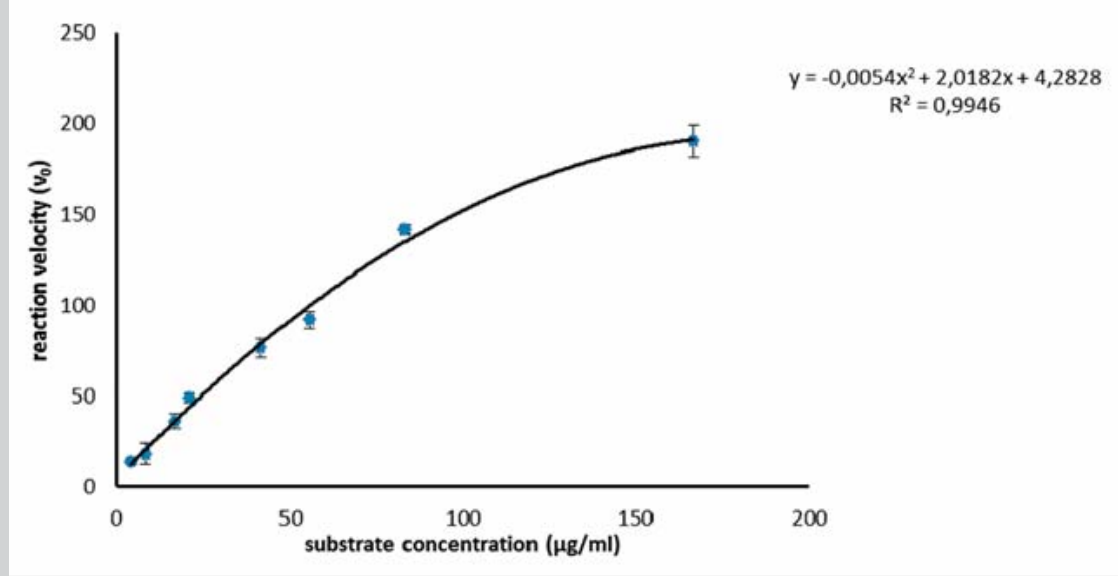

Fig. 1 Michaelis Menten equation performed with eight different MMP-2 fluorogenic substrate concentrations ranging from 4.17 to $166.67 \mu \mathrm{g} / \mathrm{mL}$ (initial conc.); enzyme: $100 \mu \mathrm{g} / \mathrm{mL}$ (initial conc.). (Color figure available online only.)

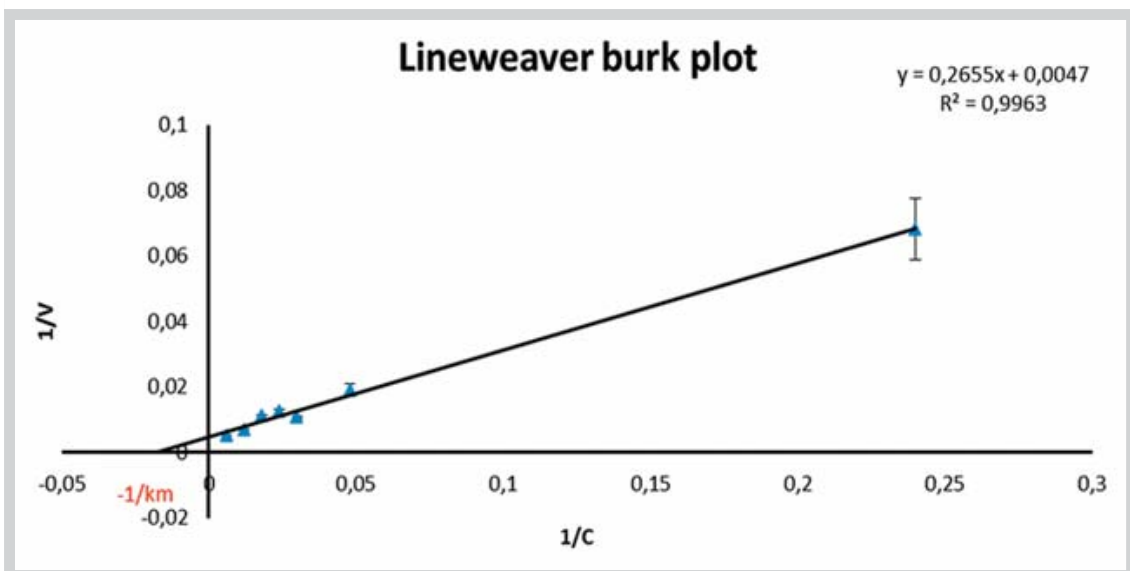

Fig. 2 Lineweaver burk plot resulting in a $\mathrm{Km}$ of $51.7 \mu \mathrm{M}(12.9 \mu \mathrm{M}$ final). This was done in order to determine the initial substrate concentration required for a consistent reaction. (Color figure available online only.) sources for new active biomolecules, as they are known to produce potent photoprotective metabolites for their defense. To date, only a few studies support the collagenase inhibition potential of natural products isolated from marine algae. Among the compounds tested so far, oligosaccharides, marine polyphenols, and fatty acids have been found to inhibit MMP-2 and MMP-9 [12]. However, to the best of our knowledge, this is the first study that investigates mycosporine-like amino acids (MAAs) for their collagenase inhibition potential. In addition, no marine substance has been tested on bacterial collagenase (chlostridiopeptidase A). The investigated compounds were isolated from marine red algae and assayed for their inhibitory potential against microbial collagenase from Clostridium histolyticum. Molecular modeling was used to depict potential interactions between the isolated compounds and the enzyme. Furthermore, we validated and optimized the anti-collagenase assay for high-throughput screening (HTS) purposes.

\section{Results}

$\nabla$

Assay optimization was initiated by the evaluation of the optimal enzyme to substrate ratio. This was necessary because a broad range of different substrate and enzyme concentrations is described in the literature. Moreover, those assays vary in the types of substrates and enzymes and none of these previously conducted assays has been validated, which makes a comparison of generated data rather difficult. Therefore, optimization was set by testing different enzyme concentrations, ranging from $400 \mu \mathrm{g} / \mathrm{mL}$ to $40 \mu \mathrm{g} / \mathrm{mL}$ (initial concentration), resulting in an optimum concentration of $100 \mu \mathrm{g} / \mathrm{mL}$ (initial), which showed a suitable ratio of enzyme activity. To optimize the substrate concentration, the Michaelis Menten constant $(\mathrm{Km})$ and the maximum velocity $\left(\mathrm{V}_{\max }\right)$ were determined by measuring the velocity of MMP-2 fluorogenic substrate conversion in a concentration range from $4.17 \mu \mathrm{g} / \mathrm{mL}$ to $166.67 \mu \mathrm{g} / \mathrm{mL}$ (initial concentrations; - Fig. 1). The values for $\mathrm{Km}(51.67 \mu \mathrm{M})$ and $\mathrm{V}_{\max } 212.76 \mu \mathrm{mol} /$ min were obtained by linear regression of the Michaelis-Menten curve (Lineweaver Burk plot), as shown in $\odot$ Fig. 2. As the enzyme constantly cleaves the substrate, the concentration of the latter is diminished during the assay, resulting in increasing nonlinearity of the reaction when [S] $<<\mathrm{Km}[13]$. Therefore, the optimum substrate concentration was chosen around the determined value of $\mathrm{Km}$. A final substrate concentration of $13.89 \mu \mathrm{g} / \mathrm{mL}$ was used in all experiments. The established ratio of approximately one part of enzyme $(100 \mu \mathrm{g} / \mathrm{mL})$ to two parts of substrate $(55.55 \mu \mathrm{g} / \mathrm{mL})$ showed a stable reaction performance, as indicated by a linear curve over more than $30 \mathrm{~min}$ of the reaction time ( Fig. 3). Longer reaction times resulted in trending slightly to a maximum. In a next step, the optimal reaction temperature was assessed by 


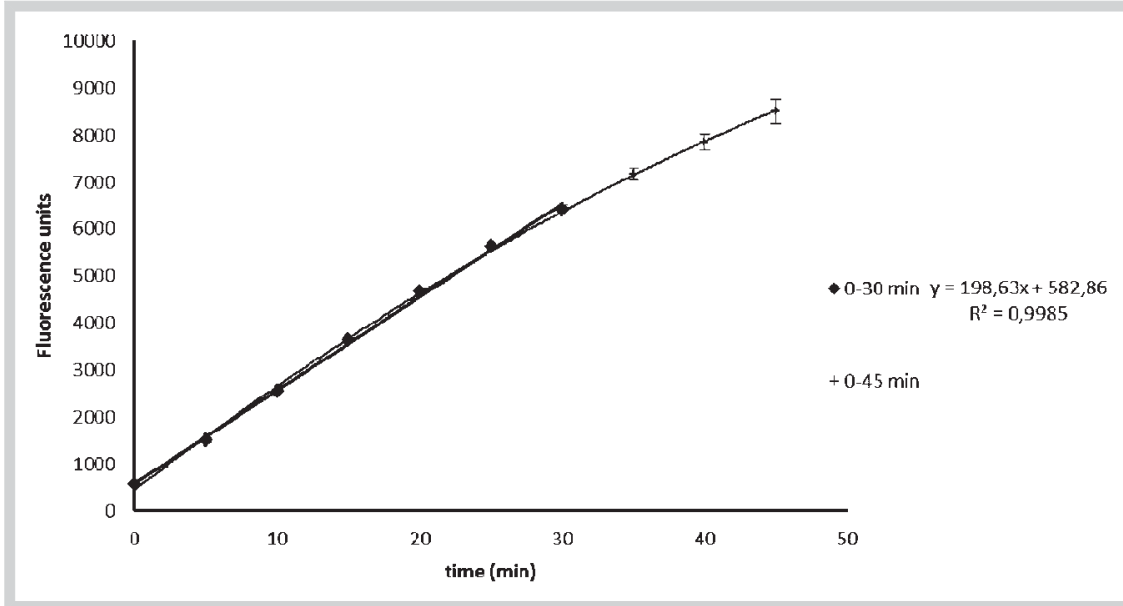

Fig. 3 Confirmation of a linear and time-dependent cleavage of the substrate under optimized assay conditions; 0-30 min: linear conditions; $0-$ 45 min: a longer assay duration leads to nonlinearity.

performing the assay at room temperature (RT), $30^{\circ} \mathrm{C}$, and $37^{\circ} \mathrm{C}$ and by using the standard inhibitor phosphoramidon at an initial concentration of $50 \mu \mathrm{g} / \mathrm{mL}$. For $30^{\circ} \mathrm{C}$ and $37^{\circ} \mathrm{C}$ reaction temperature, the same inhibition rate of $53.4 \%$ was obtained, while at RT, the inhibition was only slightly decreased (49.1\%). This indicates that in case thermo-labile substances are tested, the assay could also be carried out at temperatures around $25^{\circ} \mathrm{C}$. For MAAs this was not required, thus the incubation time was evaluated at $37^{\circ} \mathrm{C}$. The optimum incubation time of inhibitor-enzyme reactions was also investigated. No measurable differences were observed in the inhibition rate of phosphoramidon whether the incubation time was set to 5,10 , or $15 \mathrm{~min}$. Longer incubation times, however, resulted in lower rates of enzyme inhibition; for example, an incubation time of 20 min resulted in a $10 \%$ lower inhibitory capacity compared to that of $15 \mathrm{~min}$. The utilized collagenase was stable in a concentration of $1 \mathrm{mg} / \mathrm{mL}$ when kept on ice for up to $6 \mathrm{~h}$. Finally, assay validation was carried out with phosphoramidon and 1,10-phenanthroline, two standard inhibitors reported in the literature [14-16]. Incubation was carried out at $37^{\circ} \mathrm{C}$ for $10 \mathrm{~min}$, and the reaction was monitored over $30 \mathrm{~min}$. The tested concentration range for phosphoramidon was from 0.78 to $62.5 \mu \mathrm{g} / \mathrm{mL}$ (final concentration). An $\mathrm{IC}_{50}$ of $18.8 \mu \mathrm{M} \pm 1.6(11.07 \mu \mathrm{g} / \mathrm{mL} \pm 1.30)$ was determined for phosphoramidon (Mr 587.47). The concentration range for the second standard inhibitor 1,10-phenanthroline (Mr 180.21) ranged from 6.25 to $250 \mu \mathrm{g} / \mathrm{mL}$, and the $\mathrm{IC}_{50}$ value was calculated to be $238.1 \mu \mathrm{M} \pm 3.4(42.86 \mu \mathrm{g} / \mathrm{mL} \pm 1.35)$. This result does not indicate a significant or physiologically relevant inhibition, but the value is in accordance with the literature [16].

Method validation was carried out via the endpoint reading mode and kinetic mode. For the latter, fluorescence was measured every $5 \mathrm{~min}$ over a total assay period of $30 \mathrm{~min}$. The area under the curve (AUC) was calculated for seven different concentrations for the standard inhibitor phosphoramidon (serial dilution steps). For each approach, the $\mathrm{IC}_{50}$ of phosphoramidon was calculated ( Fig.4). In addition, the limit of quantification (LOQ) and limit of detection (LOD) were determined. Table 1 compares the two different approaches of data analysis. As can be seen, both ways of data evaluation are comparable to each other. Validation results are slightly better in the endpoint reading mode and are more useful for high-throughput screening purposes. However, the kinetic reading mode shows a consistent evaluation of inhibition based on a given time frame and not only in terms of a value of fluorescent units at a certain point in time.
NMR data of the isolated compounds and their stereochemistry were in agreement with the literature $[17,18]$. Palythine, porphyra, and shinorine are based on the same cyclohexenimine structure, and the amino acid, which is conjugated to the ring system in position 3, is always glycine (- Fig. 5).

The isolated substances were tested using the fully validated procedure described above. The $\mathrm{IC}_{50}$ values for palythine and shinorine were evaluated using eight serial dilutions in a concentration range from 12.5 to $125 \mu \mathrm{g} / \mathrm{mL}$ (final concentration). The $\mathrm{IC}_{50}$ value of palythine was found to be $158.9 \mu \mathrm{M} \pm 3.2(38.82 \mu \mathrm{g} / \mathrm{mL} \pm$ $0.78)$, and that of shinorine was $104.0 \mu \mathrm{M} \pm 3.7(34.42 \mu \mathrm{g} / \mathrm{mL} \pm$ 1.23). Porphyra was diluted in a concentration range from 1.87 to $150 \mu \mathrm{g} / \mathrm{mL}$, and an $\mathrm{IC}_{50}$ value of $105.9 \mu \mathrm{M} \pm 2.3(37.73 \mu \mathrm{g} / \mathrm{mL} \pm$ 1.95) was calculated. The three MAAs showed a moderate inhibition of collagenase ( $\triangle$ Table 2 ), even the determined values were lower than for 1,10 -phenanthroline $(238.1 \mu \mathrm{M} \pm 3.4 ; 42.86 \mu \mathrm{g} /$ $\mathrm{mL} \pm 1.35)$, a standard inhibitor for collagenase described in the literature $(70.4 \mu \mathrm{g} / \mathrm{mL})$ [16]. The results are comparable to inhibitors found in higher plants such as ecdysteroids, with $\mathrm{IC}_{50}$ values from $28-50 \mu \mathrm{g} / \mathrm{mL}$ [16]. Others, like (+) catechin-aldehyde polycondensates ( IC $_{50}$ values from 200 to $350 \mu \mathrm{M}$; [14]) and epigallocatechingallate $\left(\mathrm{IC}_{50}=114 \mu \mathrm{g} / \mathrm{mL}\right.$; [15]), are less active than the investigated MAAs. No marine species or substances have been tested on bacterial collagenase (clostridiopeptidase A) so far. Yet, a small number of substances, like marine saccharides (chitooligosaccharides), glycosaminoglycan from L. vannamei, flavonoids, and fatty acids from a marine source, have been investigated for their MMP-2 (gelatinase A, collagenase type IV) and MMP-9 (gelatinase B; type IV precursor collagenase) inhibition in cell lines [19].

To rationalize collagenase inhibition on a structural level, we performed in silico docking studies for porphyra, palythine, and shinorine to the crystal structure of collagenase $\mathrm{G}$ from $C$. histolyticum (PDB: 2Y6I) [20]. We generated the protein structure using protonate3d [21] and ionized the MAAs for neutral $\mathrm{pH}$ in MOE (Molecular Operating Environment MOE 2014.09; Chemical Computing Group, Inc.). Water molecules coordinating the active site $\mathrm{Zn}^{2+}$ ion were preserved to mimic the peptide-bound state resolved in the crystal structure with observed docking results. We used MOE's default settings for flexible docking including placement by Triangle Matcher, scoring by London dG, a forcefield refinement of 30 intermediate poses, and rescoring by GBVI/WSA dG. We introduced additional pharmacophore constraints during docking, enforcing an acidic group coordinating 


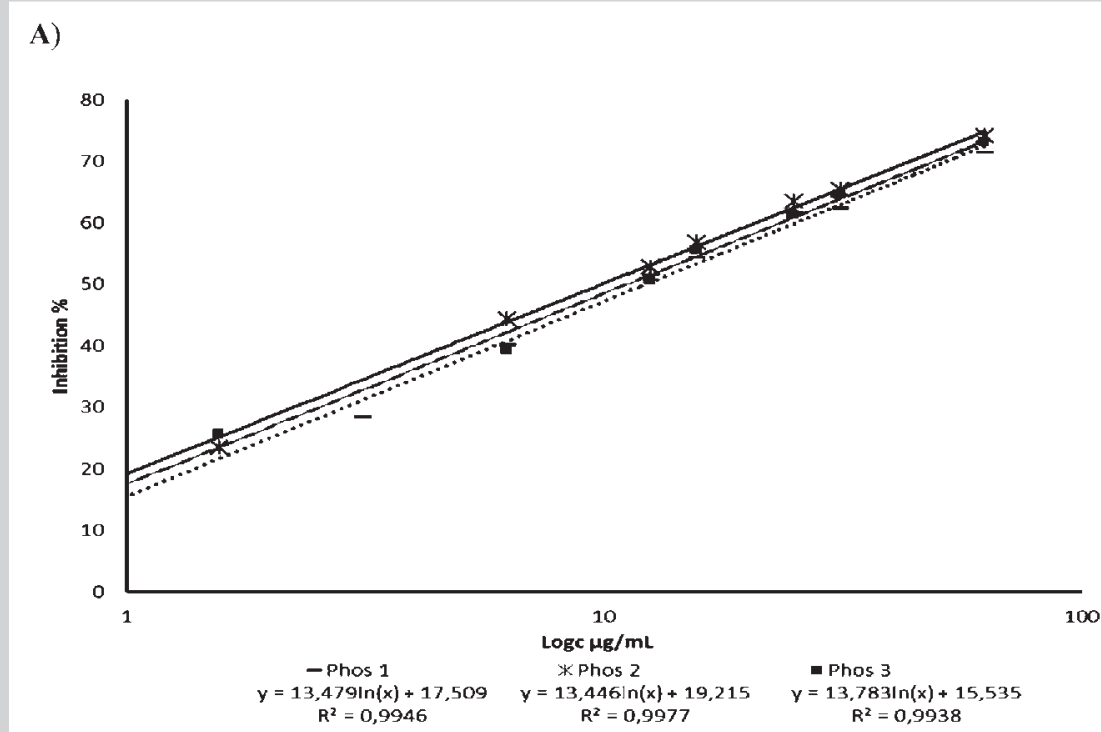

Fig. $4 \quad \mathrm{IC}_{50}$ value of the standard inhibitor phosphoramidon as determined by the endpoint reading $(\mathbf{A})$ or calculated based on the AUC from 0 to $30 \min (\mathbf{B}) ; \mathrm{n}=3$.

B)

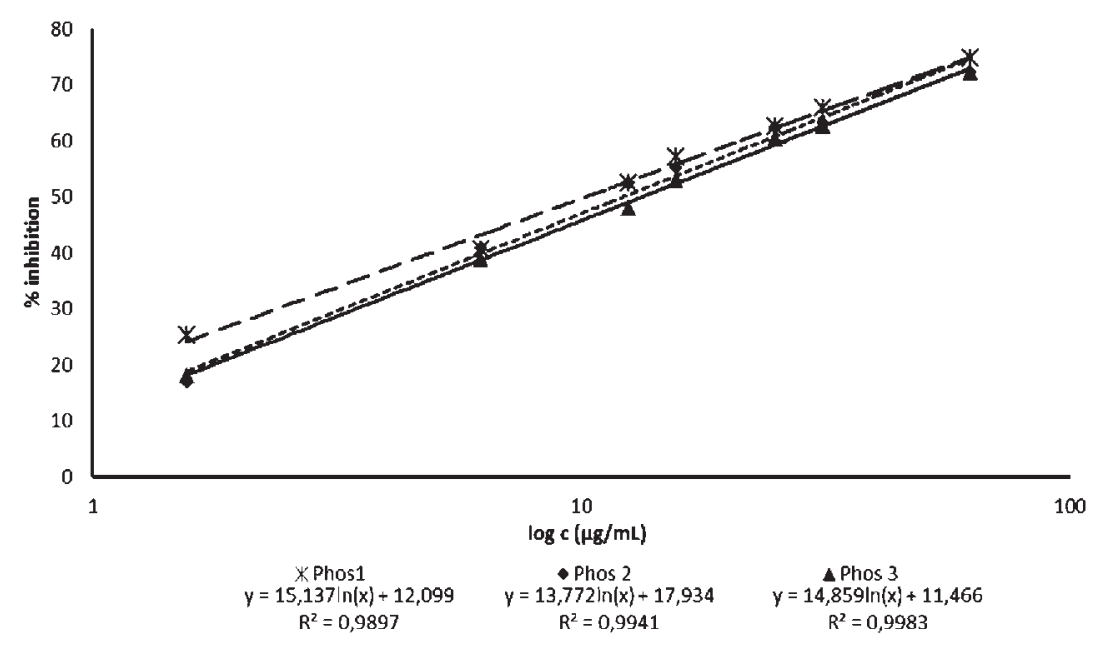

\begin{tabular}{ll} 
Parameter & Endpoint reading mode \\
\hline Linearity & 1) $Y=-1400 \ln x+8932.2, R^{2}=0.9936$ \\
& 2) $Y=-1512 \ln x+9152.2, R^{2}=0.9957$ \\
& 3) $Y=-1183 \ln x+8503.3, R^{2}=0.9913$ \\
\hline$I_{50}$ & $11.07 \mu g / m L \pm 0.95$ \\
\hline Linear range & $62.5-0.78 \mu \mathrm{gL}$ \\
\hline LOD $/ \mathrm{LOQ}$ & LOD: $1.14 \mu \mathrm{mL} / \mathrm{mL}$ \\
& LOQ: $3.47 \mu \mathrm{g} / \mathrm{mL}$
\end{tabular}

to the $\mathrm{Zn}^{2+}$ ion as well as a hydrophobic group in the S2 pocket, thus replacing the proline side chain in the native peptide position P2'. Resulting complexes were visualized using the software package Pymol (version 1.5.0.2) [22]. Poses are shown in † Fig. 6, and docking scores are given as Supplementary Information.

The three investigated MAAs are predicted to occupy a similar region within the binding site of the collagenase that overlaps with the native peptide's $\mathrm{P}^{\prime}-\mathrm{P} 3$ ' region. The $\mathrm{Zn}^{2+}$ ion is consistently bound to the carboxylate group of the glycine substructure in the MAA, replacing the native $\mathrm{P} 1$ ' glycine residue. This nicely

\section{Kinetic reading mode (AUC)}

1) $Y=-657.3 \ln x+3883.0, R^{2}=0.9906$

2) $Y=-639 \ln x+3812.6, R^{2}=0.9991$

3) $Y=-923.5 \ln x+5066.1, R^{2}=0.9869$

$11.95 \mu \mathrm{g} / \mathrm{mL} \pm 1.28$

$62.5-0.78 \mu \mathrm{g} / \mathrm{mL}$

LOD: $2.45 \mu \mathrm{g} / \mathrm{mL}$

LOQ: $7.43 \mu \mathrm{g} / \mathrm{mL}$
Table 1 Comparison of the endpoint reading mode at $30 \mathrm{~min}$ vs. the kinetic reading mode $(0-$ $30 \mathrm{~min}$ ) using the standard inhibitor phosphoramidon as an example $(n=3)$. matches the strong preference of collagenases for small amino acids at the P1' position $[23,24]$. The MAA's hydrophobic rings occupy the position of the $\mathrm{P} 2$ ' proline, again matching collagenases' preferences for this particular amino acid. The larger MAAs shinorine and porphyra stretch further towards the S3' pocket. As all MAAs are predicted to occupy the catalytic center of collagenase, a competitive binding mode would be expected, whereby the compounds are expected to inhibit the enzyme due to direct coordination to its active site. 


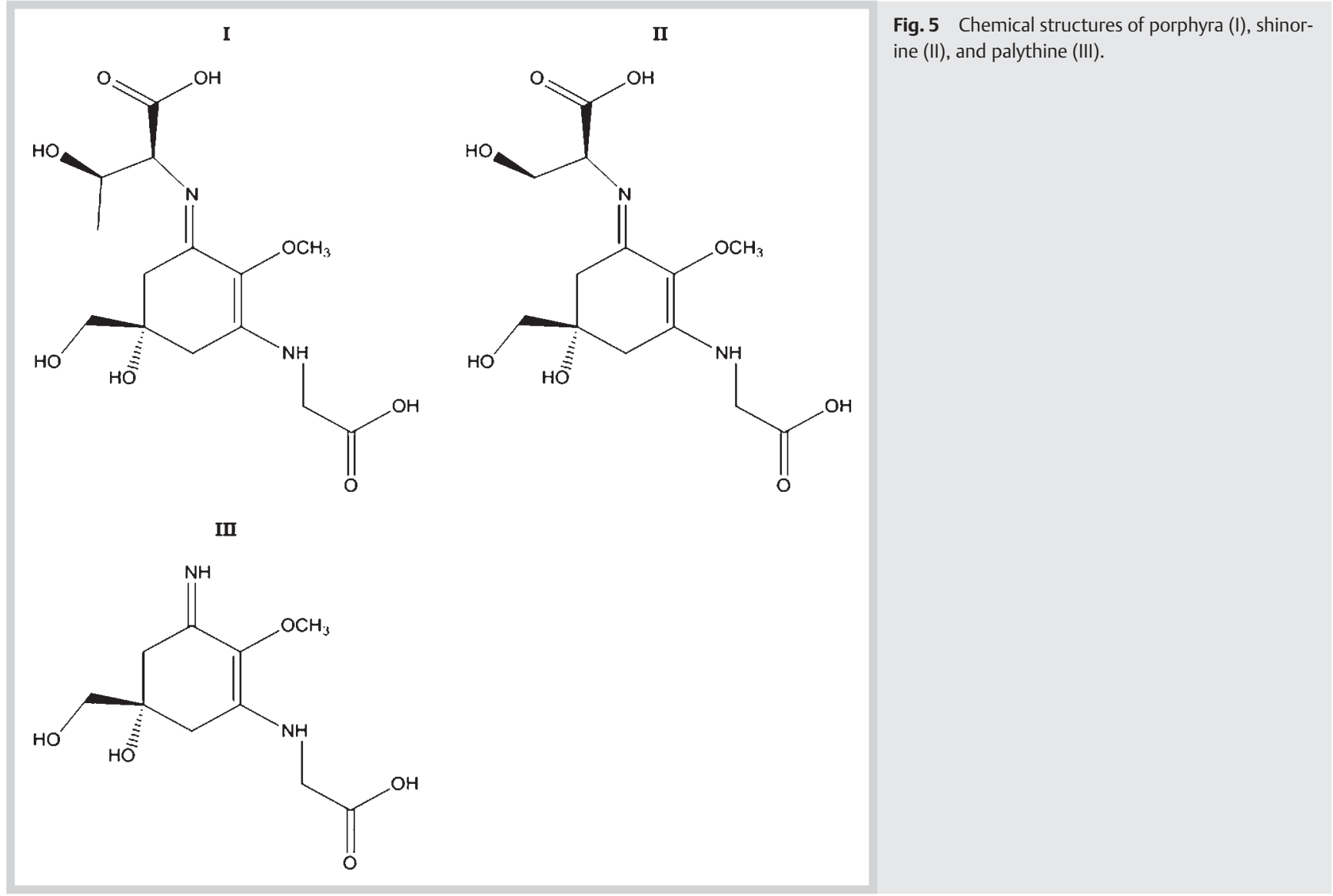

\section{Discussion}

\section{$\nabla$}

A number of collagenase inhibitors isolated from higher plants are described in the literature, belonging to different compound classes like flavonoids [25,26], catechines [27], polyphenols (e.g., resveratrol) $[28,29]$, or steroids [16]. Also, several multicomponent extracts were reported to inhibit collagenase activity [15]. Only a few attempts were made to utilize marine algae as a source for potential collagenase inhibitors, although these organisms are enormously rich in bioactive compounds that are produced in response to UV light. This includes MAAs, which derive from the shikimic acid pathway with 4-desoxygadusol as a direct precursor molecule. The latter is known to be a strong antioxidant [30]. MAAs also act as ROS scavengers after UV radiation exposure [31,32]. Being known as sunscreen compounds, MAAs could also play a role in collagenase metabolism, a fact that never has been investigated before. Several different assay protocols are described in the literature for the identification of collagenase inhibitors from natural sources [29,33-35]. In many cases, bacterial collagenase from $C$. histolyticum was used because of its unique and extensive degradation ability on collagen compared to vertebrate collagenases [36]. Therefore, this type of enzyme was selected in our experiments. Substrates reported in the literature varied a lot, largely due to the applied detection mode (fluorescence vs. absorbance) [29,33]. However, none of the described assay procedures was validated, and thus the results of different studies are hardly comparable. By presenting a fully validated method for high-throughput screening purposes of collagenase inhibitors for the first time, we established a protocol that ensures reproducible results.
To the best of our knowledge, this is the first study on mycosporine-like amino acids serving as collagenase inhibitors. Even the observed effects on collagenase are moderate, MAAs, which are already known as sunscreen compounds, could possibly serve as anti-skin aging molecules. It is possible that they protect against wrinkled skin as a result of chronically aging or photoaging. Additionally, they may have beneficial effects in the prevention of skin cancer. All these aspects can serve as an interesting starting point for the development of new cosmetics or skin protective products. To date, over 30 different MAAs, mainly from marine sources, are known, which shows that possible applications are not limited to the compounds tested here. Our results indicate many options for the use of marine MAAs in the cosmetic or pharmaceutical industry.

\section{Materials and Methods \\ $\nabla$}

\section{Reagents and chemicals}

Collagenase type V from C. histolyticum (EC 3.4.24.3), fluorogenic substrate peptide MMP-2 (MCA-Pro-Leu-Ala-Nva-DNP-Dap-AlaArg- $\mathrm{NH}_{2}$ ), phosphoramidon disodium salt (purity $>97 \%$ ), and the protease inhibitor 1,10-phenanthroline (purity $>99 \%$ ) were purchased from Sigma-Aldrich. All other solvents used for isolation and extraction (methanol, butanol, hydrochloric acid, and acetonitrile) were of analytical grade and purchased from Merck. Black 96-well plates with flat bottoms came from BD Biosciences. 


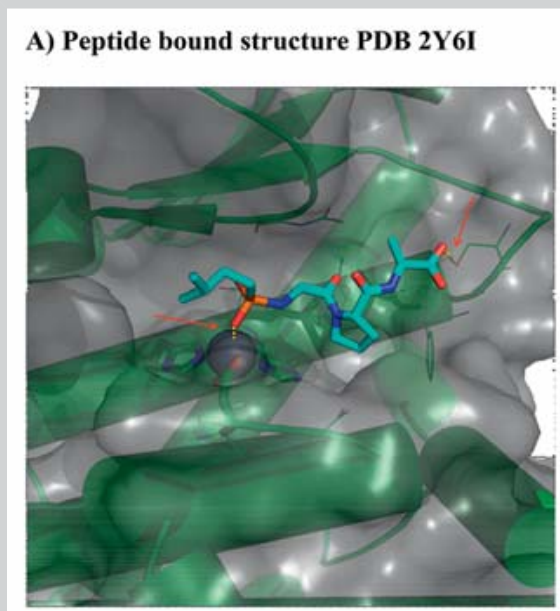

\section{B) Palythine}

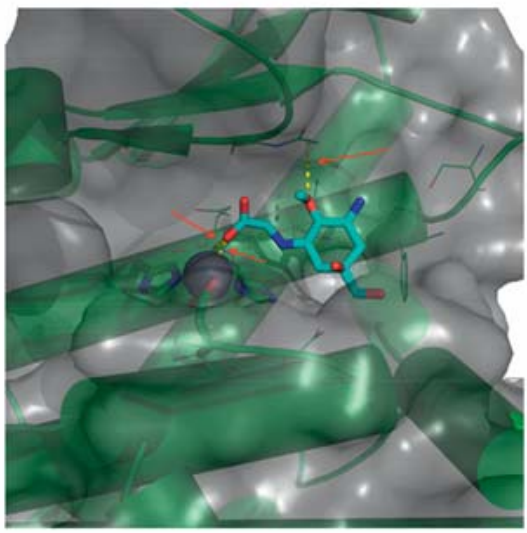

D) Shinorine

C) Porphyra
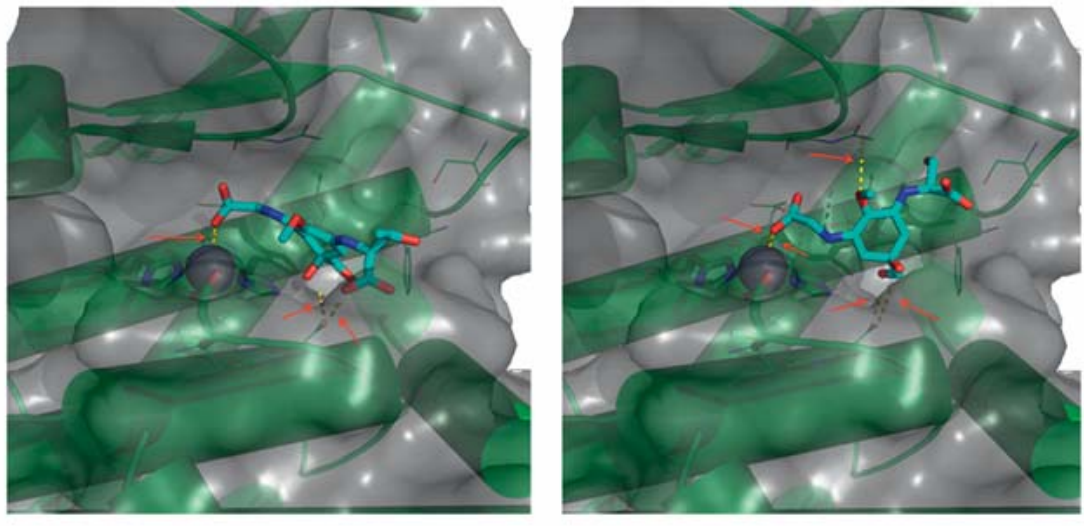

Fig. 6 Predicted binding modes of MAA to collagenase. Protein is shown as a green cartoon and semitransparent Van der Waals surface with the active site $\mathrm{Zn}^{2+}$ represented as a grey sphere. Side chain heavy atoms of metal coordinating amino acids are shown as sticks; pocket residues as thin lines. Hydrogen bonding and metal coordination are indicated as yellow dotted lines and marked with arrows. A Experimental binding mode of the peptidederived inhibitor isoamylphosphonyl-Gly-Pro-Ala (PDB: 2Y6I). Ligand heavy atoms are shown in stick representation in atomic coloring with carbon in cyan. B-D Predicted binding modes of the MAA porphyra, shinorine, and palythine. (Color figure available online only.)

\section{Biological material and extraction}

For the isolation of MAAs, two commercially available algae, Palmaria palmata (Irish Seaweeds, LOT-Nr. 5391513420184) and Porphyra sp. (Asia Express Food, LOT-Nr. 120516) were used. The material was identified by microscopic means by one of the authors (A. Hartmann), and respective vouchers (2014-MAA-1 and 2014-MAA-2) are deposited at the Institute of Pharmacy, University of Innsbruck, Austria. Dried algal material was crushed to powder in a grinding mill prior to extraction using methanol/ water $(25: 75)$ in an ultrasonic bath (Bandelin Sonorex $35 \mathrm{KHz}$ ) at $45^{\circ} \mathrm{C}$ for $2 \mathrm{~h}$ [37]. After centrifugation at $3000 \mathrm{rpm}$ for $10 \mathrm{~min}$, the supernatant was collected and evaporated at $45^{\circ} \mathrm{C}$ in a vacuum evaporator (Büchi). To obtain completely dried extracts, the resulting pasty liquid was transferred into a beaker and lyophilized (Heto power dry PL 6000, Thermo Fisher).

\section{Isolation of MAAs}

Dried extracts were dissolved in water and partitioned three times with 1-butanol to remove less polar components. The water fractions were combined, evaporated, and separated on an ion exchange resin (Dowex 50WX H $\mathrm{H}^{+}$form, 100-200 mesh, Sigma-Aldrich) according to the protocol of Carignan et al. [38]. Briefly, the resin was placed in a glass column, the sample (aqueous solution) was applied, and the column was first rinsed with water. The elution of MAAs containing fractions was possible with $0.25 \mathrm{M} \mathrm{HCl}$. To remove high salt concentrations, the obtained fractions were then applied on activated carbon cartridges (Supelco Envi-Carb, Sigma) and washed with water. Finally the
MAA-enriched fractions were eluted with pure methanol. Individual MAAs were isolated from these pre-purified extracts by semipreparative HPLC on a Dionex UltiMate 3000 preparative HPLC system (Thermo Fisher). The optimum separation was carried out on a Lichrosorb C18 100 Å column $(200 \mathrm{~mm} \times 10.00 \mathrm{~mm}$; $7 \mu \mathrm{m}$ ) from Merck by using a mobile phase comprising $0.1 \%$ acetic acid in water (A) and acetonitrile (B). The method was run isocratic for 30 min with $2 \%$ mobile phase B. Then the column was washed for $10 \mathrm{~min}$ with $90 \% \mathrm{~B}$ before being re-equilibrated for $15 \mathrm{~min}$ prior to the next injection. Detection was performed at $320 \mathrm{~nm}$, the column was maintained at $20^{\circ} \mathrm{C}$, and the flow rate was set to $0.8 \mathrm{~mL} / \mathrm{min}$. The injected sample volume was $70 \mu \mathrm{L}$ with a sample concentration of $25 \mathrm{mg} / \mathrm{mL}$. After approx. $40-50$ injections, $13.0 \mathrm{mg}$ of porphyra and $8.5 \mathrm{mg}$ shinorine (both with a purity of $\geq 95 \%$ ) were obtained from the pre-purified extract of Porphyra sp. Palythine $(7.8 \mathrm{mg}$, purity $\geq 94 \%)$ could be isolated from $P$. palmata using the same strategy. Detailed information on the isolation steps including HPLC chromatograms are provided as Supporting Information.

During separation and purification, the performance of each step was monitored by repeated HPLC-MS analysis, using an HP 1100 HPLC system from Agilent, coupled to an Esquire 3000 plus iontrap mass spectrometer (Bruker). For analysis in an analytical scale, a Luna C-18 column $(250 \times 3.00 \mathrm{~mm}, 5 \mu \mathrm{m}$, Phenomenex $)$ was used under the same conditions as described above, only the flow rate was set to $0.5 \mathrm{~mL} / \mathrm{min}$. MS spectra were obtained in alternating ESI modes by setting the temperature to $350^{\circ} \mathrm{C}$ 
Table 2 Collagenase inhibitory activity of the tested compounds.

\begin{tabular}{lr} 
Compound & IC $_{\mathbf{5 0}}(\boldsymbol{\mu M})$ \\
\hline Shinorine & $104.0 \pm 3.7$ \\
\hline Porphyra & $105.9 \pm 2.3$ \\
Palythine & $158.9 \pm 3.2$ \\
Phosphoramidon & $18.8 \pm 1.6$ \\
1,10-Phenanthroline & $238.1 \pm 3.4$
\end{tabular}

Values represent mean $\pm S D(n=3)$

and the nebulizer gas (nitrogen) to $40 \mathrm{psi}$, with a nebulizer flow (nitrogen) of $8 \mathrm{~L} / \mathrm{min}$.

\section{Structural analysis of MAAs}

NMR spectra were recorded at $25^{\circ} \mathrm{C}$ on an Ultra-Shield $600 \mathrm{MHz}$ instrument (Bruker) using the following experiments: ${ }^{1} \mathrm{H}$ - and ${ }^{13} \mathrm{C}-\mathrm{NMR}$, two-dimensional correlation spectroscopy (2D COSY), heteronuclear multiple quantum coherence (HMQC), and heteronuclear multiple bond coherence (HMBC). All samples were dissolved in deuterated water, and tetramethylsilan (both from Euriso-Top) was used as an internal standard.

\section{Collagenase inhibition assay}

The fluorimetric assay was carried out in a 96-well microplate format on an Infinite F 200 pro microplate reader equipped with filter-based technology (Tecan). The general framework of the assay was taken from the literature [29]. In brief, the reaction was monitored at an excitation wavelength of $320 \mathrm{~nm}$ and $400 \mathrm{~nm}$ emission wavelength, and the positive controls phosphoramidon and 1,10-phenanthroline were used as described previously [16]. However, the assay was optimized in terms of enzyme and substrate concentrations, temperature, and incubation time. A peptide with an amino acid sequence of MCA-Pro-Leu-Ala-NvaDNP-Dap-Ala-Arg- $\mathrm{NH}_{2}$ was chosen as the substrate, which contains a fluorogenic residue (7-methoxycoumarin-4-yl acetic acid; MCA). If no inhibitor is present, the latter is released by the enzyme and a constant increase in fluorescence can be measured. Using the bacterial collagenase from $C$. histolyticum has several advantages. It cleaves not only the $\mathrm{x}$-gly bond in collagen but also synthetic peptides and ECM, where it hydrolyses triple-helical collagen under both physiological and in vitro conditions [14, 15]. In favor of an HTS screening protocol, the volumes were kept to a minimum, obtaining a total final reaction volume of $100 \mu \mathrm{L}$, composed of $25 \mu \mathrm{L}$ substrate, $25 \mu \mathrm{L}$ enzyme, $25 \mu \mathrm{L}$ buffer solution, and $25 \mu \mathrm{L}$ sample/positive controls. The enzyme and substrate were dissolved in the reagent buffer ( $10 \mathrm{mM}$ Tris- $\mathrm{HCl}$; $\mathrm{pH} 7.3)$ in suitable concentrations. Both the enzyme and substrate were diluted from stock solutions to $100 \mu \mathrm{g} / \mathrm{mL}$ (initial) enzyme concentration and $55.55 \mu \mathrm{g} / \mathrm{mL}$ (initial) substrate concentration directly before use. Test samples were dissolved in water/DMSO, always maintaining a final DMSO concentration of $1 \%$ in each well. Buffer and sample solutions were added first, followed by the enzyme. This mixture was incubated for $10 \mathrm{~min}$. Finally, the readout reaction was started by adding the fluorogenic substrate. A negative control was evaluated in the same manner by adding $25 \mu \mathrm{L}$ $10 \mathrm{mM}$ Tris- $\mathrm{HCl}$ buffer to the reaction instead of the test substance. For the determination the $\mathrm{IC}_{50}$ values (MAAs and standard inhibitors) seven different concentrations were prepared in a serial dilution step. Each substance was tested in triplicate, with three replicates on each plate. In addition, a blank was taken for each sample concentration to avoid false positive results due to a possible native fluorescence of the tested substances. The half maximal inhibitory concentration $\left(\mathrm{IC}_{50}\right)$ was calculated using the following formula:

enzyme inhibition activity (\%) $=[\mathrm{FU}$ control $-\mathrm{FU}$ sample $) / \mathrm{FU}$ control] $\times 100$.

\section{Supporting information}

NMR shift values of the isolated substances porphyra, shinorine, and palythine as well as the isolation protocol for Porphyra sp. and docking scores for MAAs and phosphoramidon are available as Supporting Information.

\section{Acknowledgements}

$\nabla$

This work was financially supported by the Austrian Science Fund (FWF), project P241680. J.E. Fuchs acknowledges funding from the UK Medical Research Council (grant MR/K020919/1).

\section{Conflict of Interest}

$\nabla$

The authors declare no conflict of interest.

\section{References}

1 Smith LT, Holbrook KA, Madri JA. Collagen types I, III, and V in human embryonic and fetal skin. Am J Anat 1986; 175: 507-521

2 Woessner JF jr. The family of matrix metalloproteinases. Inhibition of matrix metalloproteinases. Ann N Y Acad Sci 1994; 732: 11-21

3 Philips N, Conte J, Chen YJ, Natrajan P, Taw M, Keller T, Givant J, Tuason $M$, Dulaj L, Leonardi D, Gonzalez S. Beneficial regulation of matrixmetalloproteinases and their inhibitors, fibrillar collagens and transforming growth factor-beta by Polypodium leucotomos, directly or in dermal fibroblasts, ultraviolet radiated fibroblasts, and melanoma cells. Arch Dermatol Res 2009; 301: 487-495

4 Philips N, Keller T, Hendrix C, Hamilton S, Arena R, Tuason M, Gonzalez S. Regulation of the extracellular matrix remodeling by lutein in dermal fibroblasts, melanoma cells, and ultraviolet radiation exposed fibroblasts. Arch Dermatol Res 2007; 299: 373-379

5 Philips $N$, Keller T, Holmes $C$. Reciprocal effects of ascorbate on cancer cell growth and the expression of matrix metalloproteinases and transforming growth factor-beta. Cancer Lett 2007; 256: 49-55

6 Fisher GJ, Datta SC, Talwar HS, Wang ZQ Varani J, Kang S, Voorhees JJ. Molecular basis of sun-induced premature skin ageing and retinoid antagonism. Nature 1996; 379: 335-339

7 Fisher GJ, Wang ZQ Datta SC, Varani J, Kang S, Voorhees JJ. Pathophysiology of premature skin aging induced by ultraviolet light. N Engl J Med 1997; 337: 1419-1428

8 Chung JH, Seo JY, Choi HR, Lee MK, Youn CS, Rhie G, Cho KH, Kim KH, Park $K C$, Eun HC. Modulation of skin collagen metabolism in aged and photoaged human skin in vivo. J Invest Dermatol 2001; 117: 1218-1224

9 Wierzchacz C, Enis S, Kolander J, Gebhardt R. Differential inhibition of matrix metalloproteinases-2, -9 , and -13 activities by selected anthraquinones. Planta Med 2009; 75: 327-329

10 Park HY, Lim H, Kim HP, Kwon YS. Downregulation of matrix metalloproteinase-13 by the root extract of Cyathula officinalis Kuan and its constituents in IL-1 $\beta$-treated chrondrocytes. Planta Med 2011; 77: 1528-1530

11 Lee SJ, Hong S, Yoo SH, Kim GY. Cyanidin-3-0-sambubioside from Acanthopanax sessiliflorus fruit inhibits metastasis by downregulating MMP-9 in breast cancer cells MDA-MB-231. Planta Med 2013; 79: 1636-1640

12 Pallela $R$, Na-Young Y, Kim SK. Anti-photoaging and photoprotective compounds derived from marine organisms. Mar Drugs 2010; 8: 1189-1202

$13 \beta$-Glucuronidase Assay. DyNA Quant ${ }^{\mathrm{TM}}$ Application Note 3. Amersham Biosciences. Available at https://www.gelifesciences.com/gehcls_ 
images/GELS/Related\%20Content/Files/1314716762536/litdoc 80623675_20110830181743.pdf. Accessed May 20, 2015

$14 \mathrm{Kim}$ YJ, Uyama H, Kobayashi S. Inhibition effects of (+)-catechin-aldehyde polycondensates on proteinases causing proteolytic degradation of extracellular matrix. Biochem Biophys Res 2004; 320: 256-261

15 Thring TSA, Hili P, Naughton DP. Anti-collagenase, anti-elastase and anti-oxidant activities of extracts from 21 plants. BMC Complement Altern Med 2009; 9: 27

16 Nsimba RY, Kikuzaki H, Konishi Y. Ecdysteroids act as inhibitors of calf skin collagenase and oxidative stress. J Biochem Mol Toxicol 2008; 22: 240-250

17 La Barre S, Kornprobst JM. Outstanding marine molecules. Weinheim: Wiley-Blackwell; 2014: 387-430

18 Klisch M, Richter P, Puchta R, Häder DP, Bauer W. The stereostructure of porphyra-334: an experimental and calculational NMR investigation. Evidence for an efficient proton sponge. Helv Chim Acta 2007; 90: 488-511

19 Zhang C, Kim SK. Matrix metalloproteinase inhibitors (MMPIs) from marine natural products: the current situation and future prospects. Mar Drugs 2009; 7: 71-84

20 Eckhard U, Schonauer E, Nuss D, Brandstetter H. Structure of collagenase $G$ reveals a chew-and-digest mechanism of bacterial collagenolysis. Nat Struct Mol Biol 2011; 18: 1109-1139

21 Labute P. Protonate3D: assignment of ionization states and hydrogen coordinates to macromolecular structures. Proteins 2009; 75: 187-205

22 De Lano W. The Pymol Molecular Graphics System (Version1.5.0.2); 2008

23 Fuchs JE, von Grafenstein S, Huber RG, Margreiter MA, Spitzer GM, Liedl $K R$. Cleavage entropy as quantitative measure of protease specifity. PLoS Comput Biol 2013; 9: e1003007

24 Hu YB, Webb E, Singh J, Morgan B, Gainor A, Gordon JA, Siahaan TD. Rapid determination of substrate specificity of Clostridium histolyticum beta-collagenase using an immobilized peptide library. J Biol Chem 2002; 277: 8366-8371

25 Huang XK, Chen S, Xu L, Liu YQ Deb DK, Platanias LC, Bergan RC. Genistein inhibits p 38 map kinase activation, matrix metalloproteinase type 2, and cell invasion in human prostate epithelial cells. Cancer Res 2005; 65: $3470-3478$

26 Rooprai HK, Kandanearatchi A, Maidment SL, Christidou M, Trillo-Pazos G, Dexter DT, Rucklidge GJ, Widmer W, Pilkington GJ. Evaluation of the effects of swainsonine, captopril, tangeretin and nobiletin on the biological behaviour of brain tumour cells in vitro. Neuropathol Appl Neurobiol 2001; 27: 29-39

27 Kirszberg C, Esquenazi D, Alviano CS, Rumjanek VM. The effect of a catechin-rich extract of Cocos nucifera on lymphocytes proliferation. Phytother Res 2003; 17: 1054-1058

28 Tang HJ, Martel K, Stribley J, Christman G. The effect of resveratrol on collagen expression in human uterine leiomyoma cells. J Soc Gynecol Invest 2006; 13: 70a-71a

29 Moon HI, Kim TI, Cho HS, Kim EK. Identification of potential and selective collagenase, gelatinase inhibitors from Crataegus pinnatifida. Bioorg Med Chem Lett 2010; 20: 991-993

30 Shick JM, Dunlap WC. Mycosporine-like amino acids and related gadusols: biosynthesis, accumulation, and UV-protective functions in aquatic organisms. Annu Rev Physiol 2002; 64: 223-262

31 Aguilera J, Bishof K, Karsten U, Hanelt D, Wiencke C. Seasonal variation in ecophysiological patterns in macroalgae from an Arctic fjord. II. Pigment accumulation and biochemical defence systems against high light stress. Mar Biol 2002; 141: 603-604

32 Llewellyn CA, Airs RL. Distribution and abundance of MAAs in 33 species of microalgae across 13 classes. Mar Drugs 2010; 8: 1273-1291

33 Barrantes E, Guinea M. Inhibition of collagenase and metalloproteinases by aloins and aloe gel. Life Sci 2003; 72: 843-850

34 Rennert B, Melzig MF. Free fatty acids inhibit the activity of Clostridium histolyticum collagenase and human neutrophil elastase. Planta Med 2002; 68: 767-769

35 Teramachi F, Koyano T, Kowithayakorn T, Hayashi M, Komiyama K, Ishibashi $M$. Collagenase inhibitory quinic acid esters from Ipomoea pescaprae. J Nat Prod 2005; 68: 794-796

36 Seifter SEH. The collagenases. In: Boyer PD, editor. The enzymes, Vol. 3. New York: Academic Press; 1971: 649-697

37 Tartarotti B, Sommaruga $R$. The effect of different methanol concentrations and temperatures on the extraction of mycosporine-like amino acids (MAAs) in algae and zooplankton. Arch Hydrobiol 2002; 154: 691-703

38 Carignan MO, Cardozo KHM, Oliveira-Silva D, Colepicolo P, Carreto JI. Palythine-threonine, a major novel mycosporine-like amino acid (MAA) isolated from the hermatypic coral Pocillopora capitata. J Photochem Photobiol B 2009; 94: 191-200 